André Toledo Porto Alves

\title{
VERDADE E LIBERDADE: SER, DEVER-SER E PODER-
} SER

Dissertação de Mestrado

Orientadora: Prof ${ }^{a}$. Dra. Jeannette Antonios Maman

UNIVERSIDADE DE SÃO PAULO

FACULDADE DE DIREITO

SÃO PAULO 


\section{ANdRÉ Toledo Porto Alves}

\section{VERDADE E LIBERDADE: SER, DEVER-SER E PODER- SER}

Dissertação de Mestrado apresentado à Comissão de Pós-Graduação da Faculdade de Direito da Universidade de São Paulo, desenvolvido junto ao Departamento de Filosofia e Teoria Geral do Direito. Orientadora: Prof ${ }^{\mathrm{a}}$. Dra. Jeannette Antonios Maman

\section{UNIVERSIDADE DE SÃO PAULO \\ FACULDADE DE DIREITO \\ SÃO PAULO}




\section{BANCA EXAMINADORA}

Prof ${ }^{\mathrm{a}}$. Dra. Lídia Reis de Almeida Prado

Prof. Dr. Edison Nunes

Prof $^{\mathrm{a}}$. Dra. Jeannette Antonios Maman

\section{UNIVERSIDADE DE SÃO PAULO \\ FACULDADE DE DIREITO \\ SÃO PAULO}

2013 


\section{RESUMO}

O pensamento ocidental entrou, em seus primórdios fundantes, em um beco, sem saber que se tratava de uma via sem saída. Quando chegado o tão esperado acabamento, não houve a recompensa sonhada, algum tipo de conhecimento pleno, mas o desânimo de uma obra não concluída. Foi necessário buscar uma saída, a qual não poderia ser outra senão a própria entrada. Assim, Nietzsche, Heidegger, Foucault, Arendt e outros redesenharam todo o percurso da filosofia até os que com desdém foram chamados poetas, os pré-socráticos, a estabelecer novas possibilidades para a já tão íntima relação entre verdade e liberdade, bem como novas possibilidades para o ser e seu modos, o dever-ser e o poder-ser, e, ainda, novas possibilidades para o próprio pensamento.

Palavras-chaves: verdade, liberdade, ser, dever-ser, poder-ser. 


\begin{abstract}
Western thought has entered, in its infancy founding, in an alley, not knowing that it was a dead end. When it reached the awaited end, there was no dreamed reward, some kind of full knowledge, but the dismay of a work not completed. It was necessary to find a way out, which could not be other than the entry itself. Thus, Nietzsche, Heidegger, Foucault, Arendt and others redesigned all the way of philosophy until those who were scornfully called poets, the pre-Socratics, to establish new possibilities for the already intimate relationship between truth and freedom, as well as new possibilities to the being and its modes, the being-ought and the being-able, and also new possibilities for thought itself.
\end{abstract}

Keywords: truth, freedom, being, being-ought, being-able 


\section{SUMÁRIO}

INTRODUÇÃO.

CAPÍTULO I - A caminho do possível.

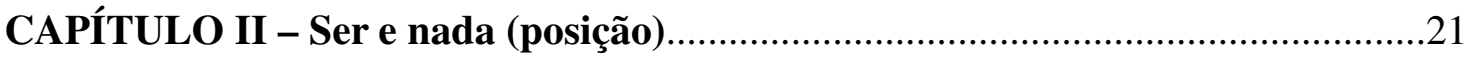

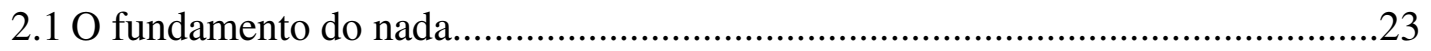

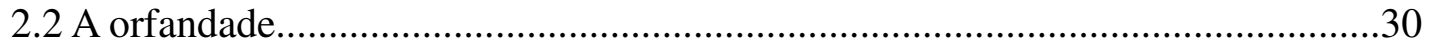

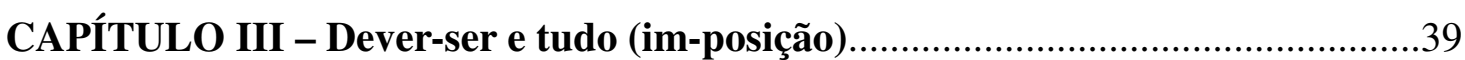

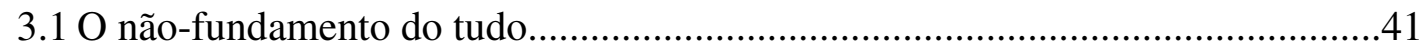

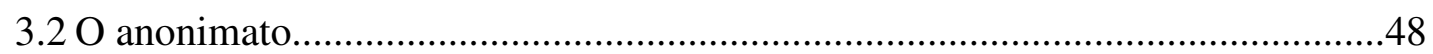

CAPÍTULO IV - Poder-ser e absoluto (com-posição).........................................63

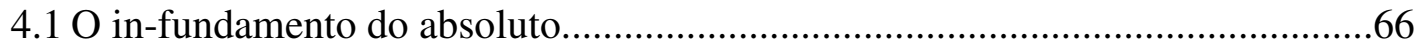

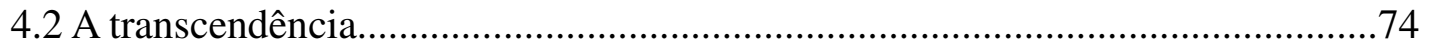

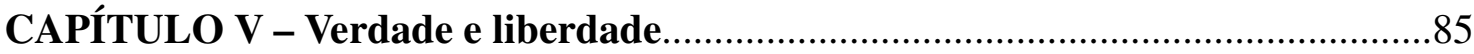

CONCLUSÃO

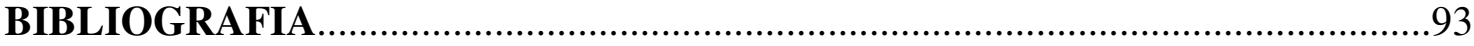

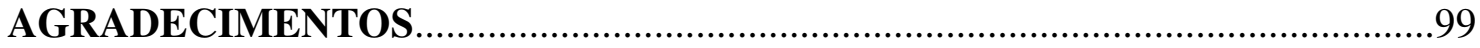

